\title{
Robottikylvön ja -kylvömuokkauksen mahdollisuudet ja haasteet Suomessa
}

Timo Oksanen ${ }^{1)}$, Raimo Linkolehto ${ }^{2)}$

1) Aalto-yliopisto, Otaniementie 17, Espoo, timo.oksanen@aalto.fi, +358-50-3160970

2) MTT, Vakolantie 55, Vihti

\section{TIIVISTELMÄ}

Peltoviljelyn kehityksessä äärimmäistä visiota edustaa täysautomaattisuus, jossa autonomisista peltotyökoneista koostuva järjestelmä suunnittelee ja toteuttaa viljelytoimenpiteet. Vision toteutuminen ulkoolosuhteissa ei ole vielä tätä päivää, vaikka kasvihuoneissa plant factory -konsepti ei ole kaukana tästä. Peltoviljelyssä haasteena on alati muuttuva ympäristö, sääolosuhteet sekä tosiasia että pellot eivät ole suljettuja alueita. Myöskään robotin siirtely pellolta toiselle julkisia teitä pitkin ei ole ongelmatonta.

iNavix-projektissa on tutkittu autonomisen traktorin avulla autonomiseen peltotyökoneeseen liittyviä haasteita. Projektin painopiste on navigoinnin ja reitinsuunnittelun tutkimuksessa, mutta kokeissa on käytetty oikeita työkoneita, joilla on tehty oikeita viljelytoimenpiteitä. Myös itse autonominen traktori on pääosin kehitetty projektin puitteissa. Kesällä 2012 työkoneena käytettiin kultivaattoria, jolla hoidettiin avokesantoa ja syksyllä 2012 kylvettiin syysviljaa 2,5 hehtaaria kylvölannoittimella. Keväällä 2013 robottikylvöä testattiin neljällä lohkolla, yhteensä 6,1 hehtaaria.

Tutkimuksessa käytetyt työkoneet ovat olleet ns. tavallisia miehitettyyn traktoriin suunniteltuja laitteita. Kultivaattori oli varustettu ns. hanhenjalkaterillä; kylvölannoitin laahavantailla. Sekä hanhenjalkaterät että laahavantaat ovat hyviä esimerkkejä siitä millaisia maata käsitteleviä teriä autonomisissa koneissa ei tulisi käyttää. Kesantopellolla kultivointi irrottaa tehokkaasti rikkakasveja, mutta hanhenjalkaterä myös kerää taaksensa näitä ja kone ei luontevasti puhdistu edes kun se nostetaan ylös maasta, vaan terän ja sen varren ympärille kerääntyneet kasvijätteet ovat tiukasti kiinni. Toisaalta laahavantailla varustettu kylvölannoitin on myös ongelmissa, jos kasvijätettä on muokatun pellon pinnassa runsaasti. Autonomisessa koneessa laahavantaissa on myös ongelmana siemenkanavan tukkeutuminen: tukkeuman puhdistuskin pitäisi automatisoida.

Kokemusten mukaan kylvötoimenpiteen automatisointi edellyttäisi myös automaattista säiliöiden täyttöä. Projektissa kehitetty kaupalliseen kylvölannoittimeen perustuva autonominen kylvörobotti pystyi kylvämään noin 0,85 hehtaaria yhdellä täytöllä, mikä käytännössä tarkoittaa että kylvörobotin isäntä ei ehdi säiliöiden täyttämisen välillä tekemään juuri muuta tuottavaa kuin käydä täyttämässä täyttövaunua silloin tällöin. Kaikissa tähän tutkimushankkeeseen liittyvissä kokeissa luonnollisesti tutkija oli koko ajan läsnä valvomassa toimintaa pellolla, koska peltorobotin prototyyppi ja avoimet pellot ovat vaarallinen yhdistelmä.

Kehitetyn peltorobotin paikannus perustuu vain ja ainoastaan tarkennettuun GPS-vastaanottimeen. Laitteiston luvattu tarkkuus on alle $5 \mathrm{~cm}$, minkä voi olettaa pitäneen paikkaansa, sillä paikannus- ja navigointivirheet yhdessä ovat niin pieniä, että pellolla kasvavasta oraasta ei pysty käytännössä erottamaan missä 12,5 cm rivivälillä kylvettyjen vetojen raja menee. GPS-vastaanottimeen liittyy kuitenkin ajallisen saavutettavuuden ongelmia ja tässä paperissa kerrotaan myös näistä kokemuksista.

Asiasanat: peltorobotti, autonominen peltotyökone, kylvökone, kultivaattori, automaattinen peltoviljely, GPS 


\section{Johdanto}

Maatalousteknologian kehittymisen tavoitteena on yleensä parantaa tuottavuutta, jotta maanviljelijä voisi tuottaa enemmän elintarvikkeiden raaka-aineita työvälineiden avulla. Maatalousteknologia on kehittynyt merkittävää vauhtia 1800-luvulta lähtien ja 1900-luvun teknologiakehityksessä maatalouden mekanisointi on arvioitu 7. tärkeimmäksi, jättäen mm. tietokoneet ja puhelimen taakseen (Cornstable \& Somerville, 2003). 1900-luvulla maatalousteknologian kehitys myös nopeutti muuta teollistumista kun maatalouden työvoimatarve väheni. Tuottavuuden trendi jatkuu edelleen, mutta mekanisointi ja koneiden koon kasvattaminen ei enää tarjoa merkittävää kehityspotentiaalia. Elektroniikka, automaatio, tietotekniikka ja tietoliikennetekniikka yhdistettynä maatalouskoneisiin voi nostaa systeemien tehokkuuden uudelle tasolle. Tätä voidaan kutsua mekatronisoinniksi tai automatisoinniksi tai robotisoinniksi, mutta nimestä riippumatta päätavoite on lisätä tuottavuutta, tuottaa enemmän ruokaa vähemmällä työvoimalla ja työllä.

Peltorobotteja tai autonomisia peltotyökoneita on ideoitu ja kehitelty pitkään, myös Suomessa (Rintanen et al., 1996). Merkittävä askel kohti autonomisia työkoneita tapahtui GPS-teknologian myötä, ensin 1990-luvun alussa kun Yhdysvallat avasi GPS-järjestelmän siviilikäyttöön ja myöhemmin 2000-luvun alussa kun "selective availability” kohina poistettiin. (Herauld \& Lange, 2009). Huolimatta paikannusteknologian kehittymisestä, kaupallinen menestys on jäänyt toistaiseksi vaatimattomaksi peltotyössä, toisaalta sama tilanne on myös autonomisten autojen kohdalla. Tuottavuuden näkökulmasta peltorobotit siirtävät maanviljelijän tai muun maataloustyön tekijän pois työkoneen kyydistä, jolloin henkilö voi tehdä muita samaan tai eri tehtävään liittyviä toimenpiteitä. Kuitenkin, peltorobottien takana ei ole pelkästään ajatus tuottavuuden parantamisesta työn nopeutumisena tms. vaan myös tarkkuuden parantumisena, niin ajan kuin paikan suhteen. Visio ”operations-on-demand” tyyppisestä peltotyöstä tarkoittaa että miehittämättömät koneet tekevät kasvinsuojelutoimenpiteitä ja sadonkorjuuta paikkakohtaisesti, ajallisesti sitä mukaa kun missäkin kohtaa toimenpiteitä tarvitaan.

Peltorobottien kaupalliseen yleistymiseen tarvitaan tiekartta, jotta prototyyppien kestävyys paranisi. Useat prototyypit ovat jo pitkään olleet esimerkiksi ajotarkkuudeltaan riittäviä, mutta ei välttämättä kestävyyden ja ympäristön olosuhteiden kannalta, jotta koneet kestäisivät tuhansia työtunteja (Blackmore et al., 2004; Jørgensen et al., 2007; Cariou et al., 2009; Nagasaka, 2009; Ruckelshausen, 2009; Bakker et al., 2010; Godoy et al., 2012).

Kun katsotaan taaksepäin maatalousteknologian historiassa, monia polttomoottorilla varustettuja traktoriprototyyppejä rakennettiin 1900- ja 1910-luvuilla, mallit ja lähestymistavat erosivat toisistaan voimakkaasti kun teknologian kehitys oli alkuvaiheessa. Mm. Englannissa alettiin järjestää 1920-luvulla ns. ”tractor trials” tapahtumia, eli suomeksi traktorikoestuksia, jotta traktorista tulisi jokapäiväinen työväline maatiloilla (Goddard, 1989). Traktorikoestuksessa ei ollut kyse ainoastaan markkinoinninedistämisestä julkisissa loppudemonstraatioissa mutta tapahtumat myös painostivat valmistajia parantamaan koneiden kestävyyttä, tehokkuutta ja käytettävyyttä, koska koneita testattiin ja verrattiin ja tulokset olivat julkisia. Ehkäpä tulevaisuudessa pitäisi järjestää samaan tapaan ”peltorobottikoestuksia”, jotta prototyypit kehittyisivät nopeammin oikeaan suuntaan.

Tässä paperissa esitellään Suomessa tehdyn peltorobottikokeen tuloksia kylvötyössä. Peltorobottikokeen tarkoituksena oli arvioida toimivuutta pitkässä työrupeamassa (vrt. pari aaria kerrallaan). Peltorobottikoe kesti puolitoista päivää, yhteensä kylvettiin 6,6 hehtaaria kevätvehnää. Tätä koetta ei kuitenkaan voi pitää varsinaisena pitkänä kokeena, mutta se paljasti kuitenkin suunnitteluvirheet ja muut kestävyyteen, häiriöherkkyyteen, jäähdytysongelmiin yms. liittyvät ongelmat.

\section{Aineisto ja menetelmät}

Peltorobottikokeessa käytettiin APU-Module traktoria ja Tume KL-2500 kylvölannoitinta. APU-Module on Aalto-yliopiston ja MTT:n rakentama autonomiseen peltotyöhön varusteltu autonominen traktori, joka perustuu Modulaire Oy:n / Tmi Kone-Sammon rakentamaan Moduli-prototyyppiin. Moduli esiteltiin alunperin vuonna 1991, päämääränä autonominen peltotyökone (Luoma, 1991). Traktori on nelipyöräohjattu ja nelivetoinen, moottoritehoa on $123 \mathrm{~kW}$ ja painoa noin $5900 \mathrm{~kg}$. Akseliväli on 2,7 m ja pyörät kääntyvät enimmillään 22 astetta. Traktorin hydrostaattinen voimansiirto mahdollistaisi suuremmankin ajonopeuden, mutta ohjausjärjestelmä rajoittaa nopeuden turvallisuussyistä max. 3.0 m/s. Kone on läpi- 
käynyt täydellisen sähkö- ja elektroniikkaremontin; vuosina 2009-2012 kehitetty elektroninen ohjausjärjestelmä, paikannusjärjestelmä, hydrauliikan säätöjärjestelmä ja navigointijärjestelmä on kuvattu tarkemmin lähteissä Oksanen (2012a; 2012b), Oksanen \& Backman (2013) ja Oksanen \& Linkolehto (2013).

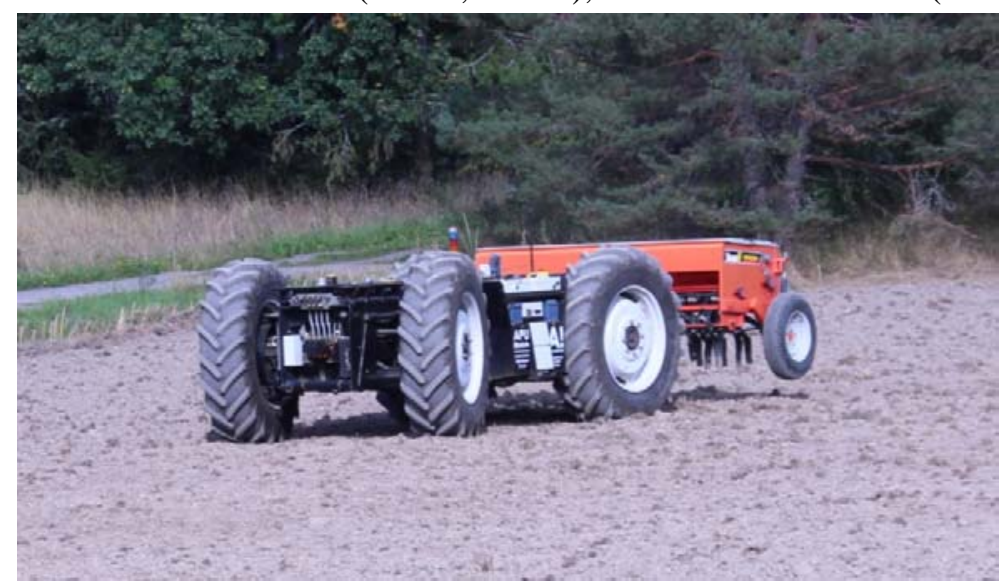

Kuva 1. APU-Module, autonominen traktori

Kylvöä varten traktori varustettiin Tume KL-2500 nostolaitekiinnitteisellä kylvölannoittimella. Kylvölannoittimessa lannoite sijoitetaan erillisillä vantailla, väli $25 \mathrm{~cm}$ ja siemenvantaiden väli on 12,5 $\mathrm{cm}$. Kylvölannoittimen työleveys on 2,5 m, joten koneessa on 20 siemenvannasta ja 10 lannoitevannasta. Kylvövantaat ovat laahavannas-tyyppisiä. Käytetyssä 25 vuotta vanhassa erinomaisessa kunnossa olevassa työkoneessa ei ollut elektronisia laitteita. Säiliöt täynnä kylvölannoitin painaa noin 1450 kg, mikä ei aiheuttanut käytetylle traktorille ongelmia. Traktorin teho ja nostolaitteen voima mahdollistaisivat leveämmänkin koneen, mutta tämä oli ainut käytettävissä ollut vaihtoehto tähän peltorobottikokeeseen.

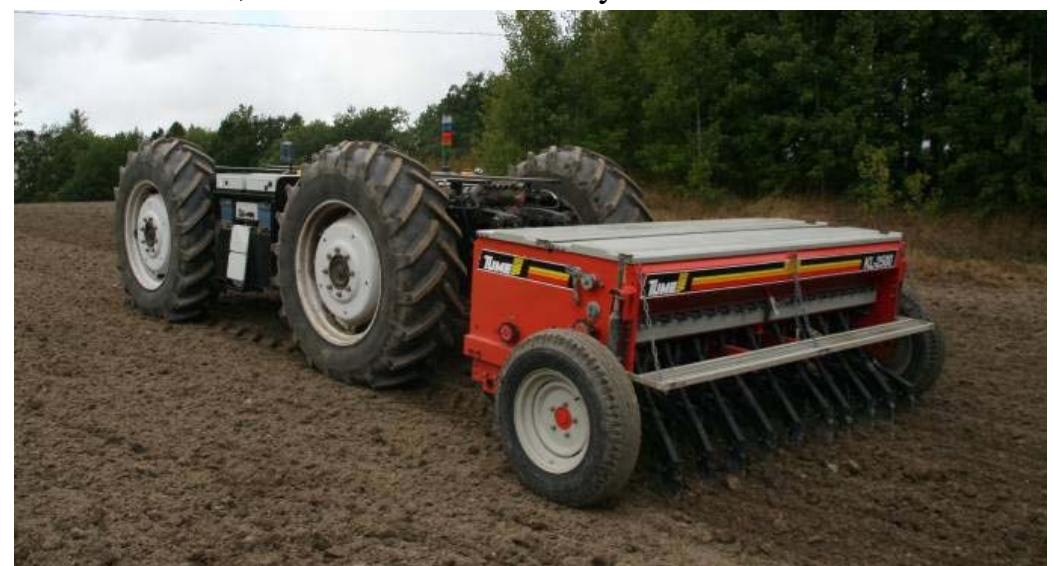

Kuva 2. APU-Module ja Tume KL-2500 kylvölannoitin peltorobottikokeessa.

Autonomisen traktorin paikannus perustuu GNSS-teknologiaan (GPS). Paikannusjärjestelmä koostuu RTK-GPS vastaanottimesta (Trimble 5700), kuituoptisesta gyroskoopista (KVH DSP-3000) ja kallistusanturista (Microstrain IMU). RTK-GPS vastaanottimen korjaussignaali tuli virtuaalitukiasemasta matkapuhelinverkon kautta. Paikannuksen tarkkuus pitäisi olla suuruusluokka $2 \mathrm{~cm}$, mutta jos näkyvissä olevien satelliittien määrä on vähäinen, tarkkuus heikkenee merkittävästi. Paikannuslaite antaa useita tunnuslukuja, jotka kertovat reaaliaikaisesti paikannustarkkuudesta: GPS fix, RTK korjaustaso, DOP arvot, pseudorange noise statistics ja kiinnitettyjen satelliittien määrä. Näitä arvoja voidaan käyttää mittaamaan paikannustiedon laatua, eli kuinka paljon paikannuslaitteen antamiin koordinaatteihin on uskominen. (Oksanen \& Backman, 2013).

Navigointijärjestelmä tarvitsee reitin, joka kuvaa pellolla tehtävän työn. Tässä tapauksessa reitti suunniteltiin ennen autonomisen ajon aloittamista, yleensä ajamalla pelto ensin manuaaliohjauksella ympäri ja kartoittaen myös sähkötolpat ja muut esteet. Reitinsuunnittelualgoritmi oli puoliautomaattinen: 
ensin seitsemän kertaa pelto ympäri vastapäivään ja sitten seurataan valitun reunan muotoa, ajaen sarka. Ensimmäisen vaiheen ympäriajossa traktori peruuttaa aina nurkissa pellon kulmaan, jotta koko pelto saadaan tarkasti kylvettyä ja sarka-ajossa ajetaan pääsääntöisesti vain eteenpäin käännöksissä, paitsi viimeiset vedot joissa käännös seuraavalle riville voi tulla tarpeen. Reitinsuunnittelualgoritmi generoi käännösradat automaattisesti samoin. Tässä vaiheessa generoidaan myös koneen nostoon/laskuun liittyvät ajonopeuden hidastusrampit. Koneen nosto tapahtuu 0,5 m/s ajonopeudessa, kylvönopeus 1,8 m/s, päistenopeus 1,5-1,8 $\mathrm{m} / \mathrm{s}$.

\section{Tulokset}

Peltorobottikoe järjestettiin MTT Vakolassa, Vihdissä, 7-8. toukokuuta 2013. Neljän annetun lohkon kokonaispinta-ala oli 6,6 hehtaaria. Peltorobottikoe järjestettiin normaalin kevätkylvön aikaan, ja sillä korvattiin kylvölannoitus, joka muuten olisi tehty muilla maatilan koneilla. Kylvömuokkaus oli tehty joustopiikkiäkeellä, tavanomaisesti. Pelloille kylvettiin kevätvehnää ja Y-lannosta, kylvösuunnitelman mukaiset määrät. Koneen säiliöt täytettiin manuaalisesti, yhdellä täytöllä oli mahdollista kylvää noin 0,85 hehtaaria - autonomisen traktorin GPS-trippimittaria käytettiin antamaan varoitus kun ala tuli täyteen.

Peltojen 1-4 pinta-alat olivat 1,07 ha, 2,40 ha, 1,76 ha ja 1,36 ha; järjestyksessä. Peltorobottikokeen pellot on esitetty kuvassa 3, annetut ulkorajat on merkitty mustalla katkoviivalla ja kylvökoneen ajolinjat harmaalla. Kolmessa neljästä pellosta käytettiin ajosuunnan valinnassa nyrkkisääntöä "pisimmän sivun suuntaisesti”, mutta pellolla 2 valittiin tästä poikkeava sääntö käytännön syystä: autonomisen traktorin operaattorin (hätäseis yms.) pitää pysytellä jatkuvasti 50m päässä koneesta langattoman yhteyden pitämiseksi yllä, ja lyhyt veto mahdollisti operaattorin pysymisen paikallaan. Samasta syystä päisteen ajosuunta on vastapäivään, koska antenni kuuluu paremmin traktorin vasemmalta puolelta katsottuna, operaattori voi seistä pellon keskellä.
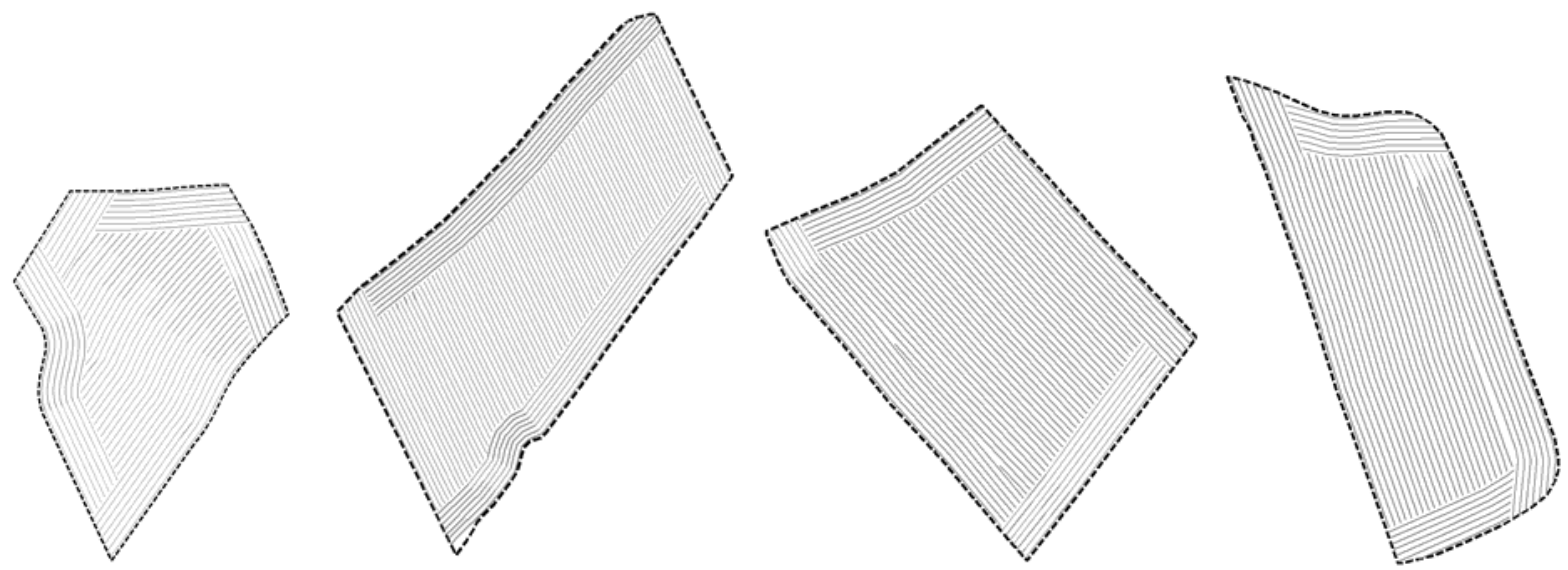

Kuva 3. Peltorobottikokeessa käytetyt pellot 1-4. Harmailla viivoilla on esitetty suunnitellut ajolinjat.

Teoriassa kehitetty ja testattu järjestelmä on autonominen. Käytännössä kuitenkin ilmeni useita seikkoja miksi oli tarpeellista että samalla pellolla oli samaan aikaan myös vähintään yksi ihminen. Ensinnäkin kylvölannoittimen säiliöt pitää täyttää aina 0,85 ha välein, eli noin kerran tunnissa. Toinen syy oli itse kylvökone, jota ei ole kehitetty autonomiseen käyttöön: joissain kosteissa paikoissa kylvövantaat saattoivat tukkeutua savimaasta mikä ei ole laahavantaille poikkeuksellista. Kun pellolla ollut henkilö havaitsi tukkeuman, koneen autonominen toiminta keskeytettiin, kylvökone nostettiin kauko-ohjaimella ylös, putsattiin vantaat soveltuvalla työkalulla ja autonominen toiminta laitettiin jatkumaan, tätä jouduttiin tekemään muutaman kerran pelloilla 1 ja 2. 


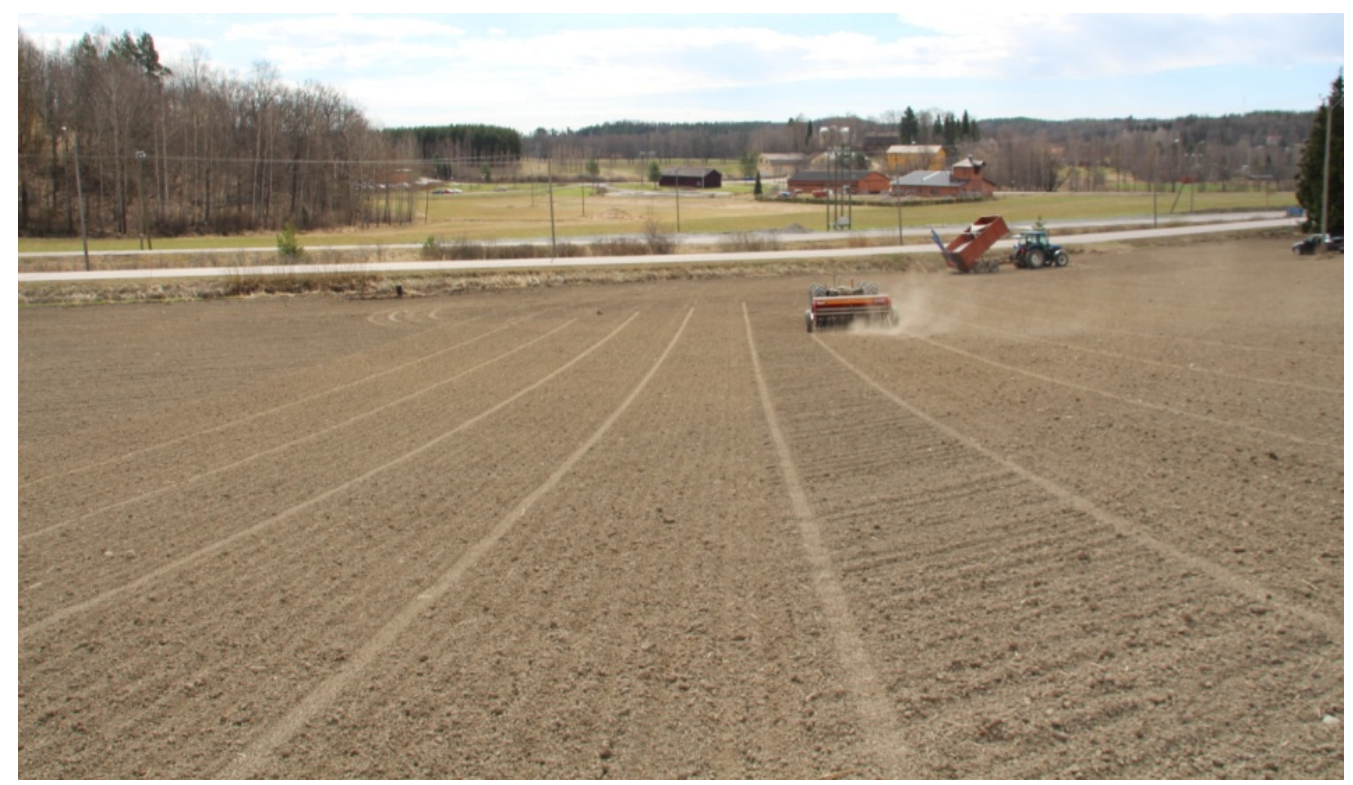

Kuva 4. Autonominen kylvö käynnissä pellolla 2. Säiliöt täytettiin manuaalisesti täyttövaunusta.

Autonomisen traktorin langaton kauko-ohjain oli toinen haaste autonomiselle toiminnalle. Technion Oy:n toimittamassa kauko-ohjaimessa on hallintavipuja koneen manuaalista käyttöä varten sekä integroitu hätäseis-toiminto jolla koneen toiminta saadaan sammutettua. Valmistaja käyttää 2,4 GHz taajuusaluetta langattomassa tiedonsiirrossa vyölle kiinnitettävän kauko-ohjaimen ja työkoneen välissä; valmistaja sanoo että protokolla perustuu IEEE 802.15.4 standardiin. Valmistaja myy kauko-ohjainta esimerkiksi nostureiden ohjaamiseen, joten turvallisuus on tärkeä sisäänrakennettu ominaisuus. Siksi langaton yhteys pitää olla jatkuva ja tiedon siirtyä molempiin suuntiin. Jos jompikumpi pää havaitsee tiedonsiirron katkeamisen, työkone menee turvalliseen tilaan, mikä tässä tapauksessa toteutettiin niin että kaikista ohjausyksiköistä, myös, dieselmoottorin ohjaimesta, katkaistaan virransyöttö ja väistämättä moottori sammuu ja kaikki liike pysähtyy.

Valitettavasti 2,4 GHz taajuusalue on hyvin ruuhkainen rakennetussa ympäristössä, ei välttämättä pelloilla, mutta kun esimerkiksi puhelimet (Bluetooth), tietokoneet (WiFi / WLAN) tai langattomat valvontakamerat aiheuttavat tälle taajuuskaistalle liikennettä häiriöiltä on myös vaikea suojautua täysin. Toiseksi lähetysteho on lakisääteisesti rajoitettu, joten maksimikantama tässä järjestelmässä on noin 50m käytännössä. Suljettu järjestelmä joka käyttää $2,4 \mathrm{GHz}$ taajuuskaistaa, rajoitettu kantama, langattoman tiedonsiirron perushaasteet (sironta, heijastus, monitieheijastus, taipuminen jne.) ja traktorin sammuttava turvatoiminto yhdessä aiheuttivat traktorin tahattoman sammumisen yhteensä 36 kertaa peltorobottikokeen aikana. Uudelleenkäynnistys ei ole vain traktorin moottorin uudelleenkäynnistys, vaan myös radioyhteyden resetointi mikä yleensä edellytti lähemmäs kävelyä: keskimääräinen järjestelmän uudelleenkäynnistysaika oli 52 sekuntia (vaihteluväli 27-92 s).

Esimerkiksi pellon 3 eri reunoissa oli kolme eri asuinrakennusta (Kuva 5), ja tämä ei ole lainkaan poikkeuksellinen tilanne Suomessa että pellon reunassa on asutusta. Pellot eivät ole turvassa $2,4 \mathrm{GHz}$ liikenteeltä, jota monet kuluttajalaitteet käyttävät (WLAN tukiasema, valvontakamerat). 


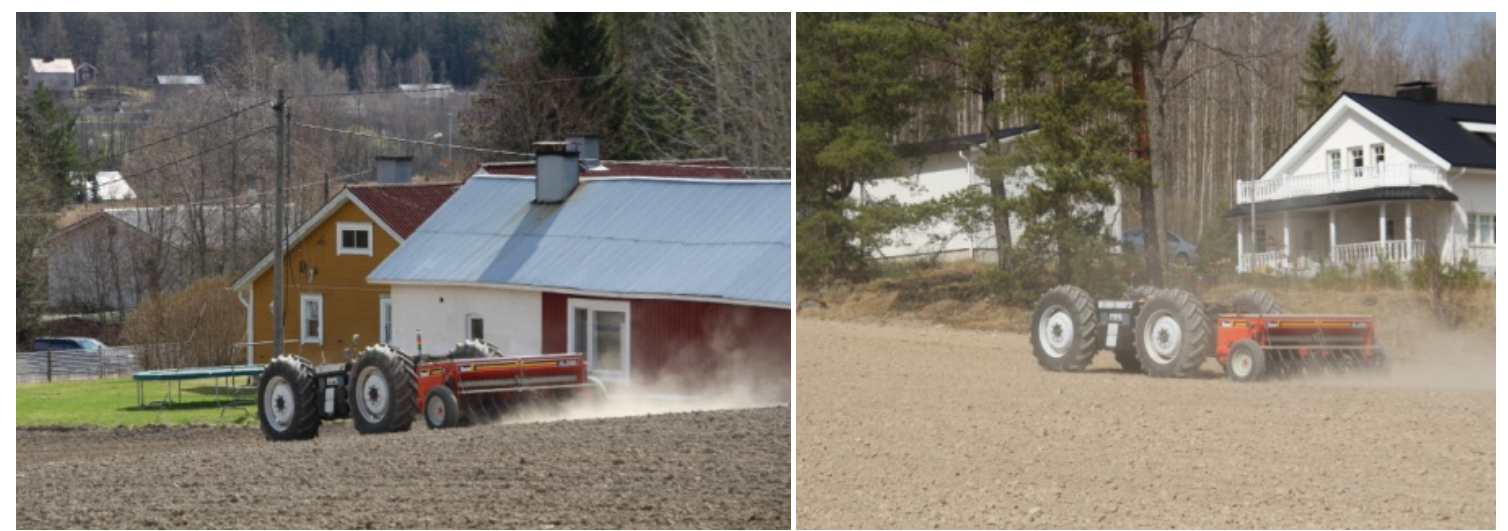

Kuva 5. Asuinrakennuksia pellon 3 ympärillä. Kotitaloudessa käytettävät kuluttajalaitteet saattavat käyttää 2,4 GHz taajuusaluetta langattomaan tiedonsiirtoon.

Peltorobottikokeessa käytetty prototyyppi sisältää paljon ns. perustekniikkaa, vastaavanlaista mitä mistä tahansa traktorista löytyy, kuten moottorin syöttöpumppu, siirtopumppu, suodattimet, hydrauliikkapumput, lauhduttimet, säiliöt, moottoriin ja polttoaineeseen liittyvät anturit yms. Aina on riski, että perustekniikka voi peltorobotissa vaurioitua. Tämä riski realisoitui peltorobottikokeen viimeisellä pellolla, kun vain puoli hehtaaria oli jäljellä, hydrauliikkajärjestelmän öljyvuoto pakotti lopettamaan kokeen. Tämän vuoksi peltorobottikokeen kokonaispinta-alaksi tuli 6,1 hehtaaria.

Peltorobottikoe saatiin toteutettua lukuun ottamatta viimeisen pellon konerikosta johtunutta keskeytystä. Taulukossa 1 on esitetty peltorobottikokeeseen liittyvät ajalliset tunnusluvut. Järjestelmä sammui yhteensä 36 kertaa peltorobottikokeen aikana tahattomasti (langaton häiriö tms). Manuaalisia keskeytyksiä oli yhteensä 35 kertaa, joista useimmiten putsattiin vantaita, tarkasteltiin kylvölannoittimen säiliöiden täyttöastetta tai säädettiin kylvökoneen syvyyttä, työntövartta tms. Hätäseis-painiketta ei tarvinnut painaa kertaakaan, manuaalinen keskeytys voidaan tehdä koskettamalla manuaalista ajonopeusvipua kaukoohjaimessa. RTK-GPS signaali putosi alle vaaditun laatutason yhteensä 30 kertaa, mikä on suhteellisesti katsoen huomattavasti enemmän hidastava tekijä kuin tahattomat sammumiset, sillä keskimääräinen toipumisaika oli ja on pidempi. GPS-paikannuslaitteen antama signaali putosi alle navigointijärjestelmän vaatiman tason yhteensä 1h 27min ajaksi, neljällä pellolla yhteensä. Numero olisi vieläkin suurempi, ellei paria kertaa traktoria olisi "autettu” pois metsännurkasta kauko-ohjaimella ajaen. Toisin sanoen peltorobottikokeen aikana kone odotti paikallaan paikannussignaalia yhteensä puolitoista tuntia. Yleensä syynä ei ollut RTK-korjaussignaalin katkeaminen, vaan itse GPS-satellittien "katoaminen” vastaanottimen seurannasta. Keskimääräinen satelliittien määrä oli seitsemän ja alle viidellä satelliitilla signaali tulkittiin liian huonoksi.

Yleisesti arvioiden keskeytysten määrä (tahattomat + tahalliset + GPS) oli melko suuri; vaihteluväli 11-20 kertaa per hehtaari, Taulukko 1. Kuitenkin vaihtelu autonomisten työpätkien (yhtenäinen ajo kahden peräkkäisen keskeytyksen välillä) kestossa on suuri, pisin työpätkä oli 1223s ( 20 min) ja lyhyin 2.8s. Tyypillinen työpätkän kesto (mediaani) oli 4-5 minuuttia.

GPS-vastaanottimen antaman signaalin laatu ja ominaisuudet ovat tärkeässä roolissa kun kehitetään autonomisia peltotyökoneita tai peltorobotteja, joiden paikannus perustuu edes osin GNSS (GPS) teknologiaan. Häiriöiden simulointi helpottaa häiriöitä kestävän ohjausjärjestelmän kehittämistä, koska häiriöiden toistaminen pelto-olosuhteissa on työlästä ja vaikeaa (Backman et al., 2010).

Peltorobottikokeen kylvön tarkkuusvaatimus oli että kaksi kylvöriviä eivät saa mennä päällekkäin ja toisaalta liian isoa rakoa ei saa jäädä kahden työstöradan väliin, eli päällekkäisajo 0\%. Koska kylvövantaiden väli oli $12,5 \mathrm{~cm}$, luonnollinen tarkkuusvaatimus navigointijärjestelmälle on $10 \mathrm{~cm}$ tai alle, samaa vaatimusta on käyttänyt mm. Backman et al. (2012) ja Backman (2013). 
Taulukko 1. Peltorobottikokeen ajalliset tunnusluvut.

\begin{tabular}{lllll}
\hline & Field \#1 & Field \#2 & Field \#3 & Field \#4 \\
\hline Pinta-ala (ha) & 1.07 & 2.40 & 1.76 & 1.36 \\
Käsitelty alue (ha) & 1.07 & 2.40 & 1.76 & 0.85 \\
\# tahattomat sammumiset & 6 & 10 & 13 & 7 \\
\# manuaalinen keskeytys & 6 & 10 & 11 & 8 \\
\# GPS signaalin laatu huono & 3 & 7 & 11 & 9 \\
- RTK korjaussignaali pois & 1 & 1 & 1 & 1 \\
- vähän satelliitteja / HDOP & 2 & 6 & 10 & 8 \\
\# Yhteensä keskeytyksiä & 15 & 27 & 35 & 24 \\
Pinta-ala / \# keskeytykset & 14.0 & 11.2 & 19.9 & 17.6 \\
GPS toip. aika, k-a (s) & 72 & 143 & 175 & 155 \\
GPS toip. aika, max (s) & 108 & 674 & 841 & 346 \\
Auton. työpätkä, k-a (s) & 233 & 274 & 147 & 111 \\
Auton. työpätkä, max (s) & 1223 & 818 & 880 & 611 \\
\hline \hline
\end{tabular}

Kuvassa 6 on näytetty navigoinnin suuntavirhe (angular error) ja sivuttaisvirhe (lateral error) histogrammina. Kaikkien neljän pellon tiedot on esitetty yhdessä, kun kylvölannoitin on ollut alhaalla ja ajo autonomista. Keskeytyskohdat on jätetty huomiotta. Keskimääräinen suuntavirhe on -0,06 astetta (keskihajonta 0,75 astetta) ja keskimääräinen sivuttaisvirhe $-0,15 \mathrm{~cm}$ (keskihajonta 5,91 cm). Sivuttaisvirheessä $90 \%$ näytteistä on välillä $\pm 6,2 \mathrm{~cm}$ ja $95 \%$ välillä $\pm 9,6 \mathrm{~cm}$. Pieni poikkeama suuntavirheen keskiarvossa johtuu pyöränkulmien kalibroinnista; nelipyöräohjatussa koneessa pyöränkulmien kalibrointi on tärkeää.

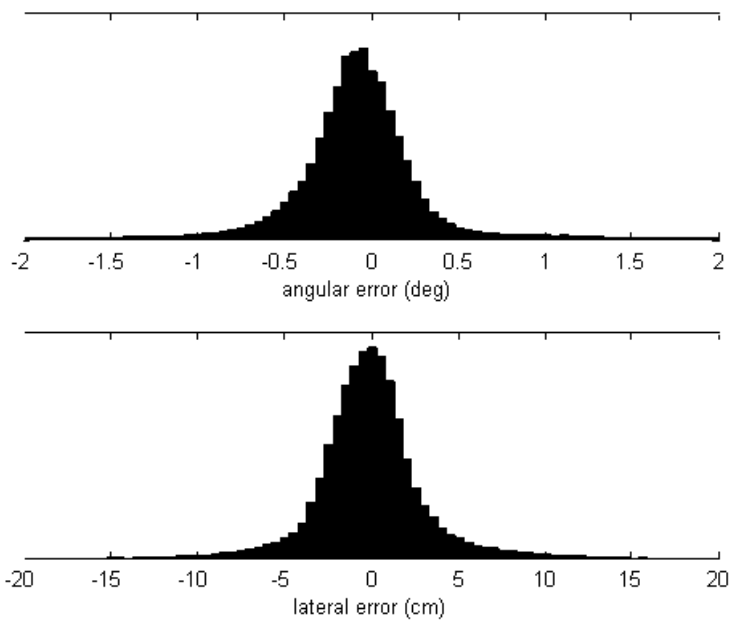

Kuva 6. Suuntavirheen ja sivuttaisvirheen histogrammi peltorobottikokeessa.

\section{Johtopäätökset}

Tässä paperissa on esitetty haasteita ja mahdollisuuksia liittyen automaattiseen kylvölannoitukseen, käyttämällä peltorobottia. Peltorobottikoe järjestettiin Vihdissä keväällä 2013. Navigointijärjestelmän saavutettu tarkkuus oli parempi kuin 10 cm, mikä on riittävä viljakasvien kylvämiseen.

Paperissa on esitetty tuloksia liittyen täysautonomisen robotin toteuttamiseen. GNSS (GPS) teknologiaan perustuva paikannusjärjestelmä kärsii metsänreunoissa ja muissa katveissa, mikä johtaa vastaanottimen antaman paikannussignaalin laadun heikkenemiseen ja putoamiseen alle vaaditun tarkkuustason. Tämän kokeen, käytetyn laitteiston ja saatujen tulosten perusteella pelkkään RTK-GPS vastaanottimeen (+asentoanturit) perustuva paikannus ei ole riittävä autonomiselle peltotyökoneelle, Suomen olosuhteissa. Laajat puuttomat peltoaukeat ovat eri asia. Yhtenä mahdollisena kehityssuuntana voidaan nähdä useaa 
teknologiaa käyttävät GNSS-vastaanottimet (esim. GPS + GLONASS), koska tällöin taivalla näkyvien satelliittien määrä teoriassa on suurempi, mutta toisaalta RTK-korjaussignaalissa pitää myös olla vastaavat tiedot.

Turvallisuuteen liittyvät järjestelmät saattavat myös heikentää työn tehokkuutta, jos operaattorin pitää jatkuvasti olla 50m etäisyydellä - jos operaattori unohtaa tämän, esim. kävellä perässä, niin järjestelmä sammuttaa traktorin ja arvokasta kylvöaikaa tuhraantuu uudelleenkäynnistykseen.

Yleisesti ottaen muutaman hehtaarin kylvön jälkeen peltorobotin valvonta alkaa olla hyvin tylsää, koska ainut työtehtävä operaattorilla on pitää käsi vapaana kauko-ohjaimen hätäseis-painikkeen painamista varten ja yrittää pysyä tarkkaavaisena havaitsemaan riskitilanteita. Avoimella pellolla seuraaminen on yksinkertaista, mutta tarkkaavaisuutta vaaditaan enemmän nurkissa, pellon reunoissa, sähkötolppien ja täyttövaunun yms. läheisyydessä. Pellolla ei saa olla yhtään ylimääräistä ihmistä kun autonominen kylvö on käynnissä. Avoimella pellolla peltorobotin operaattori joutuu seisomaan pölyssä ja polttavan auringon alla jatkuvasti, mikä ei välttämättä ole mukavampaa kuin istua traktorin ilmastoidussa hytissä. Tästä huolimatta ennen kuin täysin autonomisuus saavutetaan teknologialla ja turvallisuusjärjestelmät mahdollistavat sen, on välttämätöntä valvoa järjestelmän toimintaa jatkuvasti.

Huolimatta peltorobottikokeen aikana ilmenneistä ongelmista ja vaurioista, voidaan sanoa että peltorobottikoe oli onnistunut ja se todisti että navigointijärjestelmä ja automaatio toimii käytännön työssä, muutenkin kuin pari aaria kerrallaan.

Tulevissa peltorobottiprototyypeissä tärkeää on koestus, pitkät työrupeamat, joka paljastaa prototyypin ongelmat, kuten tässä paperissa raportoidut. Kun verrataan vuosisadan takaisiin traktorikoestuksiin, tilanne ei välttämättä ole kovin erilainen - ehkä ongelmat GPS-signaalissa ovat vastaavanlaisia kuin ensimmäisten traktorien moottorien jäähdytysongelmat?

\section{Kirjallisuus}

Backman, J, Kaivosoja, J., Oksanen, T. \& Visala, A. 2010. Simulation environment for testing guidance algorithms with realistic GPS noise model. In Proceedings of Agricontrol 2010, Vol. 3(1), 139-144.

Backman, J., Oksanen, T. \& Visala, A. 2012. Navigation system for agricultural machines: Nonlinear Model Predictive path tracking. Computers and Electronics in Agriculture, Vol. 82, 32-43.

Backman, J. 2013. Navigation system for modular agricultural machines using optimal control methods and industrial standard network. Doctoral disseration, Aalto University, School of Electrical Engineering.

Bak, T. \& Jakobsen, H. 2004. Agricultural robotic platform with four wheel steering for weed detection. Biosystems Engineering, Vol. 87(2), 125-136.

Bakker, T., Van, K.A., Bontsema, J., Muller, J. \& Straten, G. 2010. Systematic design of an autonomous platform for robotic weeding. Journal of Terramechanics, Vol. 47(2), 63-73.

Blackmore, B.S., Griepentrog, H.W., Nielsen, H., Nørremark, M. \& Resting-Jeppersen, J. 2004. Development of a deterministic autonomous tractor. CIGR International conference, Beijing, China.

Cariou, C., Lenain, R., Thuilot, B. \& Berducat, M. 2009. Automatic guidance of a four-wheel-steering mobile robot for accurate field operations. Journal of Field Robotics, Vol. 26, 504-518.

Cornstable, G. \& Somerville, B. 2003. A Century of Innovation: Twenty Engineering Achievements that Transformed Our Lives. Joseph Henry Press.

Goddard, N. 1989. Royal Shows and Agricultural Progess, 1839-1989. History Today Vol. 39(7).

Godoy, E., Tangerino, G., Tabile, R., Inamasu, R. \& Porto, A. 2012. Networked Control System for the Guidance of a Four-Wheel Steering Agricultural Robotic Platform. Journal of Control Science and Engineering, Vol. 2012.

Heraud, J.A. \& Lange, A.F. 2009. Agricultural Automatic Vehicle Guidance from Horses to GPS: How We Got Here, and Where We Are Going. ASABE Distinguished Lecture Series, 33, 1-67.

Jørgensen, R.N. et al. 2007. HortiBot: A System Design of a Robotic Tool Carrier for High-tech Plant Nursing. Agricultural Engineering International: the CIGR Ejournal. Manuscript ATOE 07 006. Vol. IX. July, 2007.

Luoma, T. 1991. Traktori kuskitta. Koneviesti 12/1991.

Nagasaka, Y. 2009. An Autonomous Rice Transplanter Guided by Global Positioning System and Inertial Measurement Unit. Journal of Field Robotics, Vol. 26(6-7), 537-548.

Oksanen, T. \& Backman, J. 2013. Guidance system for agricultural tractor with four wheel steering. IFAC BioRobotics Conference, Sakai, Japan, 27-29 March 2013.

Oksanen, T. \& Linkolehto, R. 2013. Control of Four Wheel Steering Using Independent Actuators. Fourth IFAC International Conference Agricontrol 2013, Espoo, Finland, 28-30 August 2013. 
Oksanen, T. 2012a. Embedded control system for large scale unmanned tractor. In 5th Automation Technology for Off-road Equipment Conference (ATOE) / CIGR-AgEng 2012, Valencia, Spain.

Oksanen, T. 2012b. Path following algorithm for four wheel independent steered tractor. In 5th Automation Technology for Off-road Equipment Conference (ATOE) / CIGR-AgEng 2012, Valencia, Spain.

Rintanen, K., Mäkelä, H., Koskinen, K., Puputti, J., Sampo, M. \& Ojala, M. 1996. Development of an autonomous navigation system for an outdoor vehicle. Control Engineering Practice. Vol. 4 (4), 499-505.

Ruckelshausen, A. 2009. BoniRob: an autonomous field robot platform for individual plant phenotyping. Precision Agriculture '09 (Proceedings of the european conference on precision agriculture); Wageningen, the Netherlands, 841-847. 